\title{
Improving Living Conditions of Widows: The Role of Sister Connection Organization in Burundi
}

\author{
Ndabarushimana Alexis (PhD) \\ Sociologist,Director of Academic Affairs and Research at the National \\ School of Administration, Burundi \\ Vice-President of the Network of African National Schools of \\ Administration (RENA_AFRIQUE) \\ Dushime Francine \\ Master Degree in Community Development
}

Doi:10.19044/esj.2018.v14n29p281 URL:http://dx.doi.org/10.19044/esj.2018.v14n29p281

\begin{abstract}
This paper focuses on the role of Sister Connection organization in improving the living conditions of Burundian widows. Specifically, it shows how received assistance has contributed to improving the living conditions of widows. It also shows different constraints that Sister Connection is facing in its effort of supporting widows. It further allowed us to know the suggestions that widows and the management of Sister Connection have.

We opted for qualitative approaches with the use of the interview guide, and quantitative approaches with the use of a questionnaire administrated indirectly to the widows sponsored by Sister Connection. 96 widows have been selected using Bouchard's technique. An interview protocol was conducted by the National Director and a questionnaire was administered to the 96 widows. Data findings were analyzed using the Statistical Package for the Social Sciences (SPSS). The "family systems theory" was chosen and it allowed us to understand how the solidarity that naturally characterizes Burundian families is broken at the death of a spouse and how other family members react to widows in Burundian society.

Results showed that living conditions have been improved by the financial and spiritual assistance that the widows received from Sister Connection. Furthermore, the majority of widows have benefited shelter from Sister Connection.

Despite all this effort, a significant number of widows assisted by Sister Connection are illiterate, and this presents a challenge to communicate with them whether it's through written communications or simply explaining certain things or communicating ideas. Training or teaching them becomes a challenge as they don't easily pick up on things or understand as fast as they
\end{abstract}


could. Widows live far from each other. In fact, some live in isolated areas which make it difficult to reach them and know their needs on a regular basis.

Keywords: Living conditions, Widowhood, Independent lifestyle, Sister Connection

\section{Résumé}

Cet article souligne le rôle de l'organisation Sister Connection dans l'amélioration des conditions de vie des veuves burundaises. Plus précisément, il montre comment l'assistance reçue a contribué à améliorer les conditions de vie des veuves. Il montre également différentes contraintes auxquelles Sister Connection est confrontée dans son effort de soutien aux veuves et nous a permis de connaître les suggestions des veuves et de la direction de Sister Connection.

Nous avons opté pour des approches qualitatives avec l'utilisation du guide d'entretien et quantitatif avec l'utilisation d'un questionnaire administré indirectement aux veuves prises en charge par Sister Connection. 96 veuves ont été sélectionnées selon la technique d'Alain Bouchard. Un protocole d'interview a été mené auprès de la directrice nationale et un questionnaire a été administré auprès de 96 veuves. Les données ont été analysées à l'aide du logiciel Statistique Pour les Sciences Sociales (SPSS).

La «théorie des systèmes familiaux» a été choisie et nous a permis de comprendre comment la solidarité qui caractérise naturellement les familles burundaises est rompue à la mort d'un conjoint et comment les autres membres de la famille considèrent les veuves dans la société burundaise.

Les résultats ont montré que les conditions de vie ont été améliorées grâce à l'assistance financière et spirituelle que les veuves ont reçue de la part de Sister Connection. En outre, la majorité des veuves ont bénéficié d'un abri de la part de Sister Connection.

Malgré tous ces efforts, un nombre important de veuves assistées par Sister Connection sont analphabètes, ce qui représente un défi pour communiquer avec elles, que ce soit par le biais de communications écrites ou simplement en expliquant certaines choses ou en communiquant des idées. Les former ou les enseigner devient un défi car ils ne peuvent pas facilement comprendre les choses ou comprendre aussi vite. Les veuves vivent loin les unes des autres. Au fait, certaines vivent dans des zones isolées qu'il est difficile de rejoindre, d'où les difficultés de connaître leurs besoins régulièrement.

Mots-clés: Conditions de vie, veuvage, Mode de vie indépendant, Sister Connection 


\section{Introduction}

Widowhood is a social phenomenon because it exists in all societies of the world. Most women and men marry and live as partners for at least part of their adult lives. However, higher mortality rates for men leave a lot of women living alone, especially since most widowed women do not remarry. In contrast, men generally live with a spouse. For some decades, the widowed female has outnumbered her male counterpart by an ever widening margin. Three factors account for this: (1) Mortality among females is lower than it is among males, and therefore, greater numbers of women survive to advanced years; (2) Wives are typically younger than their husbands and consequently have a greater probability of outliving them; and (3) Among the widowed, remarriage rate are significantly lower for women than for men (United Nations, 2001, p.5).

Almost worldwide, widows compromise a significant proportion of all women ranging from 7 to 16 percent of all adult women. However, in some countries and regions, the proportion is even higher. In Africa for example, there are many widows due to the HIV/AIDS epidemic. Also, armed conflict and ethnic cleansing have formed many widows. According to the UN (2000), it has been estimated that in Rwanda, 70 percent of all children are dependent on widowed mothers.

Despite advances in standard of living of the population, the living conditions of widows are deplorable in most societies. The situation is worse in developing countries with their unique social and cultural aspects, which at times ignores the basic human rights of this vulnerable section of the society. In developed countries, widowhood is experienced primarily by elderly women, while it also affects younger women in developing countries, with many of them still rearing children. Girls become widows even before reaching adulthood (UN, 2000).

Women comprise $70 \%$ of the world's poorest people and own only $1 \%$ of the titled land. They suffer not only from unequal access to education and training, but also from discrimination by their employers. In many parts of the world, widows are discriminated and treated inhumanly as if losing a husband is not causing enough sadness and grieve for a women that has been left behind. Millions of widows in the world endure extreme poverty, banishment, violence, homelessness, health problems, and other sorts of discrimination. Furthermore, these women are often blamed for their husband's death and accused of witchcraft (Lampe, 2013).

Help Age International (2011), for instance, has found that in Tanzania, hundreds of old women mostly widows have been killed because of accusations of being witches. The children of widows are often affected, both emotionally and economically. Widowed mothers, now supporting their families alone, are forced to withdraw children from school and to rely on 
their labor. Moreover, daughter of widows may suffer multiple deprivations, which increases their vulnerability to abuse (United Nations, 2011).

Widows in countries coming out of conflict are vulnerable to ongoing abuse and they often experience further violence and discrimination in the post-conflict period. Mistreatment of widows can have a negative impact on investments in peace and security, feeding the cycle of poverty, breeding unrest and insecurity, and ultimately challenging democracy and sustainable security (United Nations, 2011).

Burundi is a developing country. Repetitive wars are one of the causes of poverty in Burundi, and it has left behind helpless widows and orphans. About $90 \%$ of Burundians live in rural areas and are subsistence farmers who grow up crops and rear animals just to feed themselves and their families.

Many widows in Burundi are homeless because homes destroyed during war are irreparable and other times because they are very poor and can't build a house on their own. Family members take possession of their land and homes. Most of the time, there is no advocate to fight for their rights. Their health conditions and that of their children are bad, and they are suffering often from malaria. This makes children drop school as they become unhealthy and cannot study with an empty stomach. It is very hard for most widows in Burundi to provide for their basic needs (Sister Connection, 2017).

Facing extreme poverty, starvation, rape, HIV/AIDS, seizure of their homes and possessions and social exclusion, widows and the deprivation they face have been invisible to the public and policy makers. Their children have to often endure extreme poverty, child labor, and prostitution (United Nations, 2001).

Few widows can rely on their own earnings since participation in the labor force, either before or subsequent to widowhood, is still limited to small selected groups of women. This condition is primarily due to major disparities in the educational attainment of women in various segment of the society, depending on factors such as geographic location, level of socioeconomic development or social class. Although the female literacy rate has increased generally, half the women are still illiterate. This tends to be true mostly in underdeveloped villages and among the lower classes (Lopata, 1987, p.90).

Little attention has been directed towards research about widowhood. Other than recognizing that the widow may have financial problems for which Social Security provides assistance, few people realize what it means to be widowed (Davis \& Petchesky, 1977, p.1).

"Empowering widows through access to adequate health care, education, decent work, full participation in decision making and public life; 
more importantly, creating opportunities for them can help protect their children and avoid the cycle of inter-generational poverty and deprivation" (Ban Ki-Moon, 2011).

Social reconstruction is a priority issue which is often ignored in the context of widowhood. With the extended family, widows and their children are in need of priority assistance. Above all, aid organizations must listen to what they say. Mechanisms must be put in place to protect widow's human rights, to make them aware of their rights, and to integrate them into the new post-conflict economy so that they can fully participate in civil society and raise their children.

Sister Connection NGO is one of the organizations supporting widows and it contributes to enhancing the quality of the living standard of widows. What is the role played by Sister Connection in improving living conditions of widows? In other words, to what extend has Sister Connection assistance improved the lives of Burundian widows? What constraints is Sister Connection facing in its ministry of supporting widows? What suggestions do widows and the national director have for Sister Connection to improve more the quality of living of widows?

This paper focuses on highlighting the role of Sister Connection organization in improving the living conditions of Burundian widows. Specifically, this paper seeks to highlight how the assistance received has contributed to improving the living conditions of widows, to show different constraints that Sister Connection is facing in its ministry of supporting widows, and to know the suggestions that widows and the management of Sister Connection have.

\section{Methodology}

\section{Research Methods and Theoretical Approach}

This study was concerned with the contribution of Sister Connection NGO in improving the lives of Burundian widows. It sought to identify the kinds of assistance widows get and to show how it has improved their quality of living. Therefore, this study combined both qualitative and quantitative methods.

Generally, qualitative research seeks to describe the characteristics of a social phenomenon such as a welfare organization (Reid \& Smith, 1981, p.289). As the assessment of living conditions can also be based on quantifiable aspects, we also need to appreciate quantitatively what Sister Connection gives to widows to enable them to improve their living conditions.

Qualitative research is designed to reveal a target audience's range of behavior and perceptions that drive it with reference to specific topics or issues. It uses in depth studies of small groups of people to guide and support 
the construction of hypotheses. The results of qualitative research are descriptive rather than predictive (Qualitative Research Consultants Association, 2016). Qualitative researchers use a language of cases and contexts to examine social processes and cases in their social context. They borrow ideas from the people they study and place them within the context of a natural setting. Qualitative data involves documenting real events, recording what people say (with words, gestures, and tone), observing specific behaviors, studying written documents or examining visual images (Neuman, 2006, p.157).

The "family systems theory" explains how the family, as a system, responds to the dying member of the system.

According to Whitchurch and Constantine (1993), the interactions between different subsystems within the main system add characteristics to the whole that make it qualitatively different from each individual member of that system. A family system has components that involve interrelated elements and structures, patterns of interaction, and open or closed boundaries. Each system has subsystems, which consist of subgroups of members.

So, the "family systems theory" was chosen and it allowed us to understand how the solidarity that naturally characterizes burundian families is broken at the death of a spouse and how other family members react to widows in Burundian society.

West region is the case study of this research, and it comprises of the following provinces: Bujumbura, Bujumbura mayor ship, Bubanza, and Cibitoke. This chapter shows also how data were collected from the field. It describes the population, the sample, and data collection instruments.

\section{Target Population}

A population study is a group of individuals taken from the general population who share a common characteristic, such as age, sex, occupation, nationality or health condition.

The population of this study was of Sister Connection sponsored widows from West region in Burundi. The number of widows keep changing as more are being supported and others off assistance. Some widows can change the place of living and can remarry, but also others die. It means that there is no fixed number of supported widows each quarter. For this reason, the researcher considered the total number of assisted widows at the time of her research as the population. The list of sponsored widows was obtained from the accountant records, which was 197 sponsored widows from West region, in February 2017. Thus, it was 109 widows from west A which comprises Bujumbura mayor ship and Bujumbura province, and 88 widows from west $\mathrm{B}$ which comprises of the provinces of Bubanza and Cibitoke. 
Chart 1: Distribution of the survey population by Region

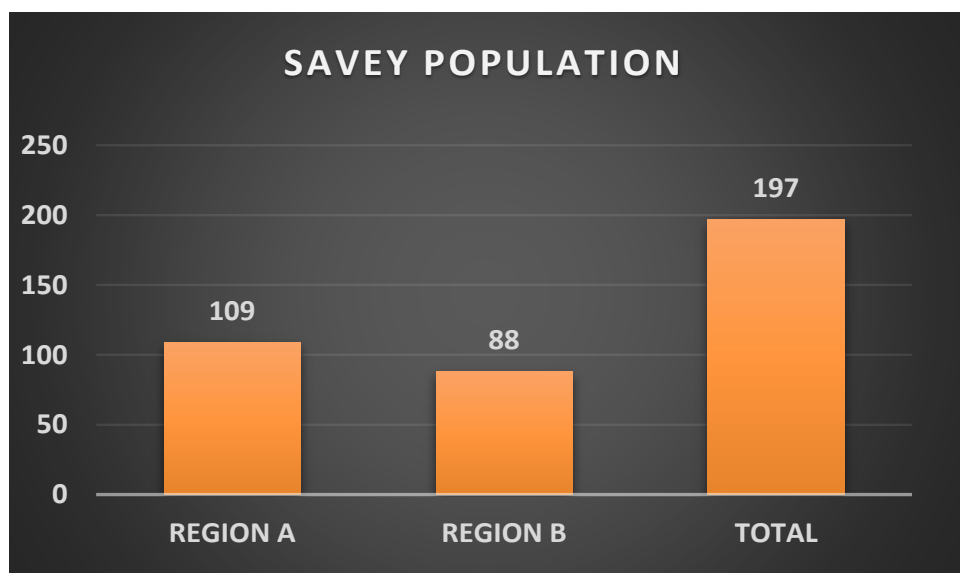

Source: Established by researchers

\section{Sample Size and Selection Techniques}

The technique of sampling for this study is purposive sampling. Purposive sampling is appropriate to select unique cases that are especially informative. It is used to select members of a difficult-to-reach, specialized population (Lawrence, 2006, p.222).

Given that not all widows of Sister Connection NGO are concerned with this study, the researchers selected consciously and purposively sponsored widows from West region for the sample in order to include directly elements that are relevant to this study. The researcher referred herself to the technical sampling of Alain Bouchard as cited by SABITI Fred (2004). According to him, "When the population of the study is equal or less than 1,000,000 individuals, it is corresponded to the sample of 96 individuals with a marginal error of 10\%" (p. 46).

Concerning our case study, the population is of 197 individuals which is less than $1,000,000$ individuals. So, the size of our sample comprises of 96 individuals. Therefore, basing on his formula, the sample is being stratified at each level of the provinces, that is, four categories in accordance with widows' home provinces. The sample has been defined as follows:

$n p c=(\mathrm{Np} \times \mathrm{Nc}) / \mathrm{N}$; where $\mathrm{npc}=$ the size of the correct sample of the stratum p.

$\mathrm{Np}=$ size of the stratum $\mathrm{p}$

$\mathrm{N}=$ size of the population

$\mathrm{Nc}=$ correct sample

$\mathrm{p}$ determines the number of each stratum

$\mathrm{N}=197$, that is, sponsored widows from West region: 62 widows from Bujumbura province, 47 from Bujumbura mayor ship, 28 from Bubanza, and 60 from Cibitoke. 
Widows from Bujumbura: 62x 96/197 = 30

Widows from Bujumbura major ship: 47 x 96/197 = 23

Widows from Bubanza: 28 x 96/197 = 14

Widows from Cibitioke: 60 x 96/197 = 29

The sample size for this study, however, constitutes 96 widows from the west region of Burundi.

Sister Connection NGO has been chosen by the researchers because it matches with this study. It is an organization that cares for widows of Burundi.

West sponsored widows are a group of participants for this study and were expected by the researchers to give information on how Sister Connection is contributing towards improving their quality of living. Widows gave information using a questionnaire and they responded to it when they came to get their financial assistance in February, 2017 at Sister Connection head office located in Ngagara quarter II, precisely in the compound of Hope Africa University in Bujumbura Mayor ship. As most of the respondents were illiterate, they could neither read nor write. So, the researchers asked questions and wrote the answers themselves. The questionnaire consisted of closed questions to collect quantitative data and open questions to collect qualitative data.

With all these parameters, the total sample size is 96 individuals taking into account the two regions $\mathrm{A}$ and $\mathrm{B}$ concerned by the study with 1 Key Informant Interview performed.

From a selected sample of 96 individuals in a finite universe of 197 households, we have proportionally distributed the samples in each stratum represented by a region. Thus, the samples selected by region are distributed on Chart 2:

Chart 2: Sample Distribution by Region



Source: Established by the researchers 
This sampling technique allowed us to identify 96 widows, that is, 30 from Bujumbura mayor ship, 23 from Bujumbura province, 29 from Cibitoke province, and 14 from Bubanza province. In order to collect data from the field for this study, two techniques, namely interview and questionnaire, were used. An interview protocol was conducted by the National Director and a questionnaire was administered to the 96 widows. Data findings were analyzed using the Statistical Package for the Social Sciences (SPSS).

\section{Results}

Demographic Data of Participants

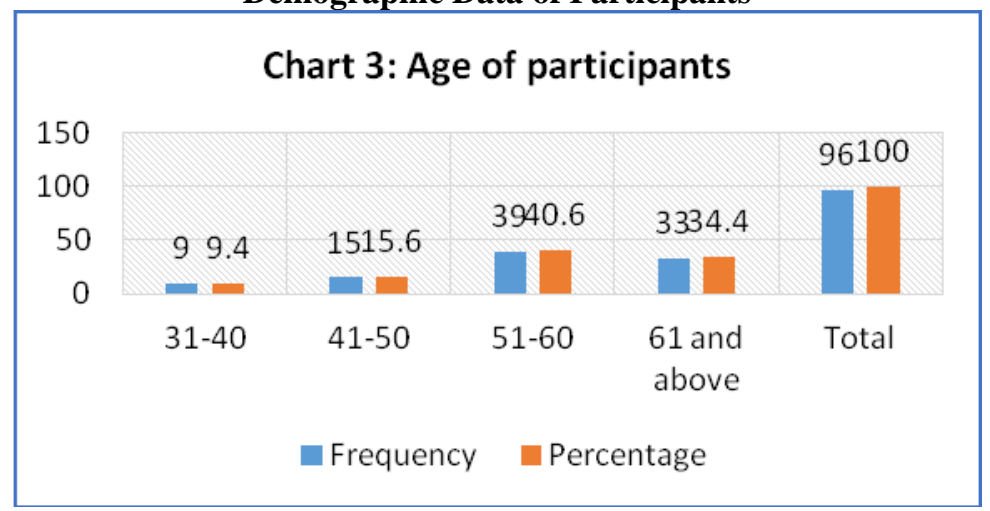

Source: Data collected from the field

Chart 3 shows us that 39 widows (40.6\%) are between the age of 51 and 60 and represents the majority of this study. 33 widows (34.4\%) are between the age of 61 and above, 15 (15.6) are between 41 and 50, while 9 widows $(9.4 \%)$ are between 31 and 40 years of age. No widows were found to be aged between 21 and 30 .

The fact that the majority of widows are between the age of 51 and 60 followed by those of 61 and above shows that they are the ones who are in great need since young widows in Burundi tend to remarry and still have enough strength to try and work in order to provide for their families. Widows in advanced age do not have strength to cultivate or do a paid job. So, they depend on others to survive. In fact, most of them may live alone without any person to support them. The number of widows aged of 61 and above is less than those aged between 51 and 60 depending on the life expectancy in Burundi.

According to the latest WHO data published in 2015, life expectancy in Burundi is: Male 57.7, female 61.6, and the total life expectancy 59.6 (World Health Organization, 2015). So it is explained by the fact that a lot of women do not reach the age of 60 which is even more understandable for widows who encounter a lot of problems in their lives. 


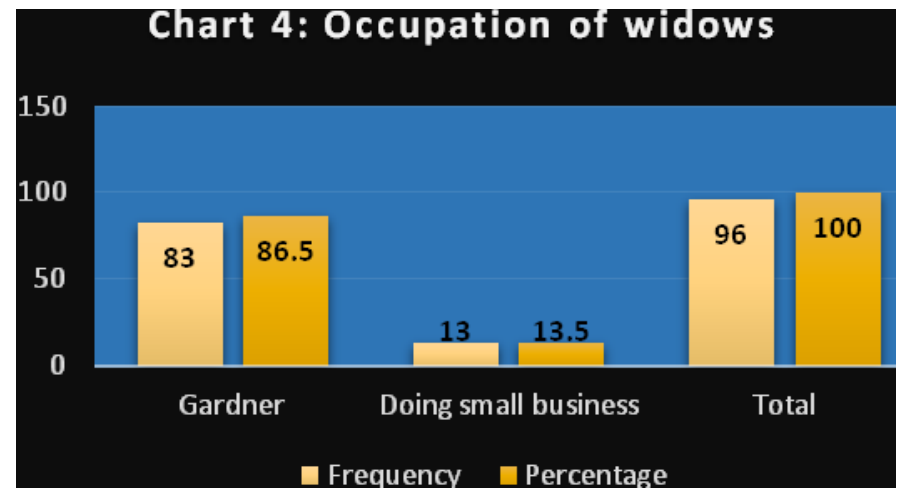

Source: Data collected from the field

Chart 4 shows that 83 widows $(86.5 \%)$ live by gardening. Only 13 widows $(13.5 \%)$ live by doing small business. This can be explained by the fact that $90 \%$ of Burundians live by subsistence agriculture. Most peasants in Burundi cultivate just to feed themselves and their families. They are not able to produce enough to eat and enough to sell so that they can meet other basic needs such as medical care, shelter, and education for their children.

The low production is due to old means of agriculture and small land possession for many Burundian families. This explains the fact that many widows in Burundi live in extreme poverty. In its national agricultural investment plan 2012-2017, the Ministry of Environment, Agriculture and Livestock (2012) stressed that "the economy of Burundi is essentially based on subsistence agriculture, characterized by a very large agricultural population (more than $90 \%$ of the total population), a fragmentation of farms (average less than 0.5ha) and very low productivity. Over the past decade, agricultural output growth (2\%) was below the population growth rate of around $2.6 \%$ to $3 \% "$ (p.3).

\section{Chart 5: Level of Widow education}

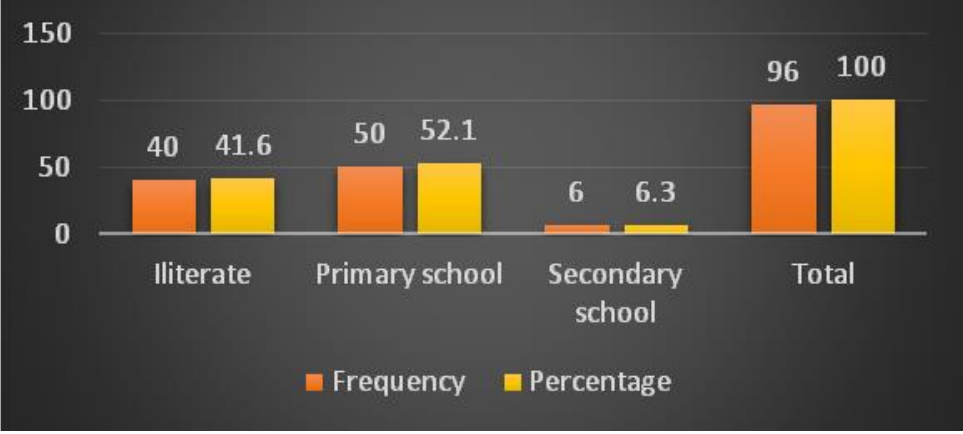

Source: Data collected from the field 
Chart 5 indicates that 50 widows $(52.1 \%)$ have studied up to primary school as their level of education. 40 widows (41.6\%) are illiterate, that is, do not know how to read or write. 6 widows $(6.3 \%)$ have gone to school up to secondary level. With these results, we can conclude that, in general, widows cannot or rarely can get a well-paid job for them to be able to provide for their needs and those of their families. These results match with those in Table 2 showing us the profession of widows that 83 out of 96 , that is $86.5 \%$, lives by subsistence agriculture.

Many women, especially in previous years, did not attend school or dropped it while in primary school because, on one hand, their parents are poor and, on the other hand, they are not encouraged to get education as there is even a saying in Kirundi that "a woman's education is to get a husband" (Amashure y'umukobwa n'umugabo).

As mentioned by Sewel and Hauser (1975), "low levels of education increase economic hardship. Individuals with low levels of education have lower incomes than those with high levels of education, in part because they are less likely to be employed, and if employed, more likely to hold low level jobs" (p.277).

Without literacy, education and training, widows can support neither themselves nor their families. A common consequence of widowhood in traditional societies is the withdrawal of children from school. The United Nations (2000) has reported that girls are likely to be the first affected: they are needed to care for younger siblings while the widowed mother begs on works. 


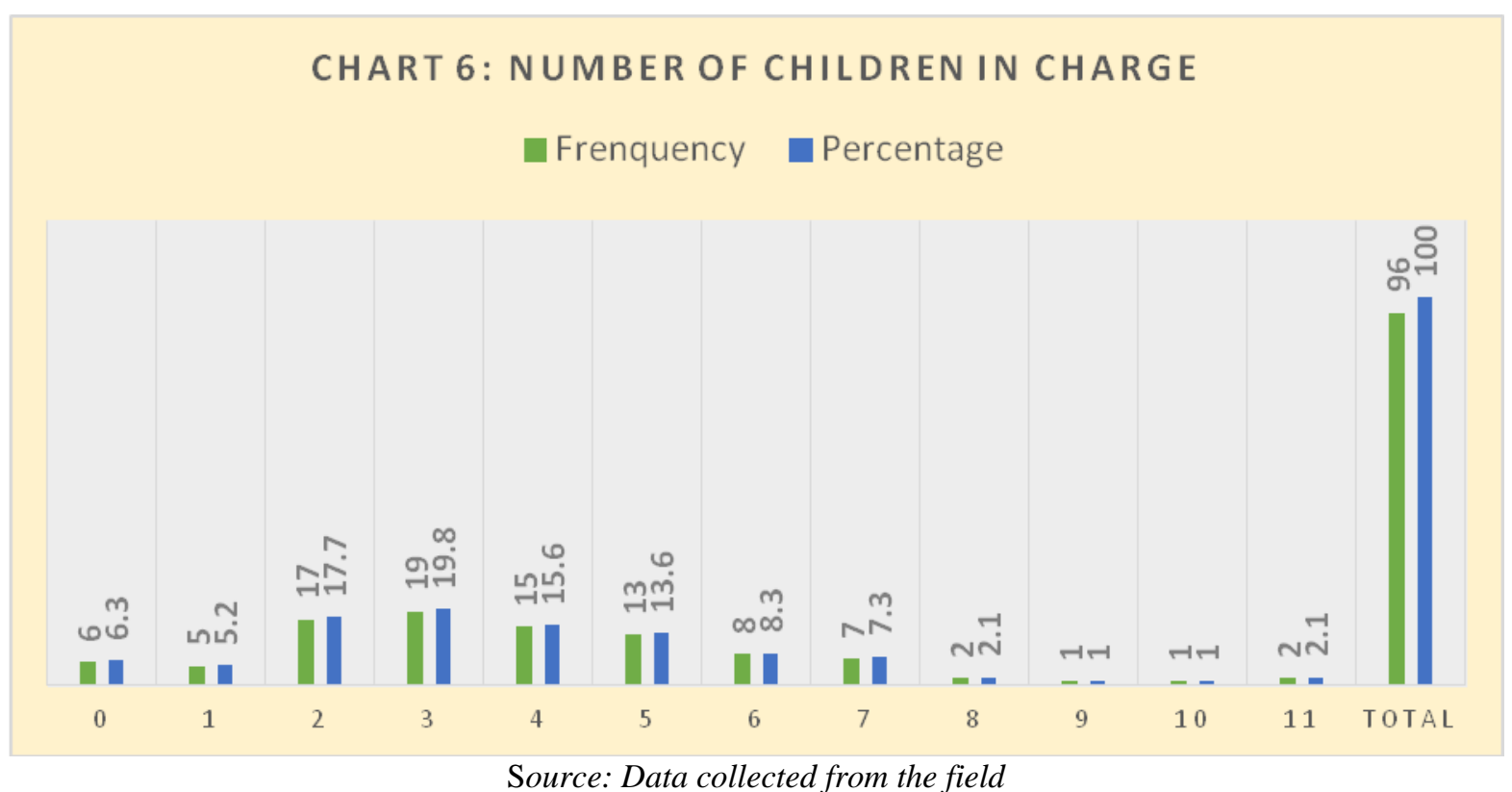

Source: Data collected from the field 
The results from the Chart 6 indicate that many of the widows are in charge of 2 to 5 children, with the majority of widows caring for 3 children (19.8\% or 19 widows).

According to the World Bank (2013), fertility rate in Burundi is at 6.03. This situation means that widows were supposed to care in general for 6 children. However, in this study, most widows have 3 children under their care because other children they are supposed to care for are married and have their own families. This matches with results from table one where 72 widows out of $96(75 \%)$ are aged between 51 and above. Moreover, the small number of children can be explained by the fact that some widows loses their husbands when they were still in the age of procreation and did not get that chance of giving birth to more children. In Burundi society, it is not easy for widows to get remarried.

\section{Quality of Life of Widows Supported by Sister Connection}

About the kinds of assistance widows get from Sister Connection, they all recognize that they are getting financial assistance, Psychological assistance, Social assistance, and Spiritual assistance.

A study conducted in Texas by Stelle and Mitsueuchida (2004) on social support focused on the stability and change in the Social support networks of widows. This study revealed that the importance of social support for adaptation in later life is fairly well established. It has been found that the study participants experienced adaptation and compensation using social support in the event of husband loss.

It has been suggested that social support plays an important role in the bereavement outcome and acts as a buffer for stressful life events. Vachon and Stanley (1988) have mentioned that there is evidence that the extent to which members of the social network provide various types of support to the bereaved is important in the pattern of recovery and adaptation.

Available confidants and access to self-help groups to assist with emotional management can help counter loneliness and promote a survivor's reintegration into the society. This is what Sister connection and other associations and NGOs are doing for Burundian widows. The social resources of finances and education have been found to be particularly influential in countering the stresses associated with the death of a partner.

Hansson and Remondet (1988) have clarified that community programs that provide education, counseling, and financial services can facilitate the efforts of the widowed and their families to restructure their lives. For most persons, widowhood need not be considered the end of productive life, but rather the beginning of a major segment of the life 
course. Also, it is something one should pursue vigorously in order for it to be successful and fulfilling.

\section{Improving the Living Conditions of Widows}

78 widows $(81.3 \%)$ affirm that their living conditions have been improved by the financial assistance they get from Sister Connection.

Putting money in the hands of a woman can have a long-term effect on the whole family. The United Nations (2001) has indicated that when women hold assets or gain income, the money is more likely to be spent on nutrition, medicine and housing, and consequently their children are healthier. In contrast, men are more likely to spend money on alcohol and other vices.

17 widows (17.7\%) affirm that their living conditions have been improved by the spiritual assistance they got from Sister Connection, while one widow got a loan. The financial assistance has improved the living conditions of widows to the extent that they are able to get food to eat, to get clothing, to send their children to school, to get medical care, to do gardening work, to rear livestock, get house supplies, to give offering and tithe in their churches and for some, to prepare weddings for their children.

In the FXB village program report (2015), we read this: "In July 2013, Cesarie's family was chosen to take part in the Buterere I FXB Village program. She received comprehensive support in the fields of nutrition, health, education, housing and economic strengthening. She began to sell vegetables and to grow rice, which she also sells to a cooperative that processes it using a specific machine made available by FXB. Alongside this, she has diversified her income streams by launching a goat rearing business, which brings her up to 300,000 Burundian francs per quarter. She now has renovated

her home with her savings, pays for $25 \%$ of medical costs and school fees for her children. Now she has an important role in the community, who elected her as head of colline."

The majority of widows $(75 \%)$ have benefited shelter from Sister Connection, which means that besides financial assistance, housing also plays a very important role in improving their living conditions.

Widows got homes because most of them were homeless. Their homes had been destroyed during war; others have been chased away by their in-laws; for others, their homes are very small, old with grass roof that it rains inside. So far, Sister Connection has built 1670 homes for widows from the year 2005. Buconyori (2017) mentioned that widows themselves have testified that they feel comfort, protection, dignity, and self-esteem when they receive a home. 
Widows are encouraged to seek control over their existence by actively construing their own life courses. The assumption is that they will adapt better if they plan for where they want to be at different potential stages during the entire course of widowhood. This plan might include the following phases: "a time for emotional recovery; a time for taking stock, reestablishing or restructuring support relationships, and formulating personal directions for the future; a time for discovering a comfortable and satisfying independent lifestyle, and for determining an approach to maintaining economic, psychological and social functioning; perhaps, a time for personal growth and change; and a time for reasoned consideration of one's last years and assertion of a degree of control over the arrangements surrounding one's own decline and death."

Establishing a new and satisfying autonomous identity after the loss of a partner is never easy. Hansson and Remondet (1988) have stressed that the probability of achieving that goal can, however, be enhanced through counseling strategies designed for individual circumstances and programs that help survivors avoid desolation coupled with meaningful social and familial support systems.

\section{Constraints that Sister Connection has in its Effort of Supporting Widows}

Sister Connection though contributing in improving the living conditions of widows has some challenges.

Burundi has so many widows who are extremely poor due to a long period of civil war and the pandemic of HIV/AIDS. Most of the time, widows in need come to Sister Connection office asking for help. It is not possible for Sister Connection to meet all their needs since it already has many registered widows who have received homes, but haven't yet received sponsorship assistance.

A big number of widows assisted by Sister Connection are illiterate and it is hard to communicate to them, that is, like getting to them written announcements, communicate ideas to them, and explaining things to them. It becomes difficult to train them because it becomes slow for them to understand.

Widows live far from each other. In fact, some live in isolated areas which make it difficult to reach them and know their needs regularly. It is very difficult sometimes to know a widow's situation, for instance, if she is very sick and needs an emergency such as operation. Most of the areas do not have electricity so that staff and social workers can get in touch with them by telephone. Others have very bad roads or no roads at all to facilitate transportation. 
Land dispute is a very big issue in Burundi. People, even members of the family, can kill each other over land issues. This is caused by the fact that most Burundians cannot get a well-paid job due to illiteracy. So, land is the only wealth they possess. Sometimes then, a widow with nobody to speak for her is forced to live her property in order to save herself and her family. As a result, Sister Connection can then find some of the widows without enough land to do subsistence agriculture.

\section{Widows Suggestions to Sister Connection Concerning its Programs}

Many widows are very concerned with the financial assistance they get from Sister Connection. 55 widows (57.3\%) suggested that Sister Connection should keep supporting them until the time they will die. This matches with the results in Table 6 where 78 widows $(81.3 \%)$ said that their living conditions have been improved by the financial assistance they get from Sister Connection. In other words, financial assistance seems to play a very important role in improving the widows' living conditions.

The consequence of loss of a husband's income on the husband's death is a straightforward issue, as the income he once earned is no longer available for the surviving wife and any dependent children. Loss of an adult male is economically devastating to already poor families. Many widows in traditional societies have no rights, or very limited rights, to inheritance or land ownership under customary or religious law. Widows then find themselves to be financially insecure and totally dependent on the charity of their husband's relatives (The Global Widow Report, 2015, p.98).

\section{Results Discussion}

This study was about describing the contribution of Sister Connection in improving the lives of Burundian widows by studying the case of widows from West region which included a sample of 96 widows from precisely Bubanza, Bujumbura, Bujumbura mayor ship, and Cibitoke provinces.

Analyzing the results, many widows in Burundi experience extreme poverty because they are just living by doing subsistence agriculture. Additionally, many of them who didn't go to school finds it difficult to get a well-paid job. This situation is similar to the one highlighted by Bradbury (1989) in her study entitled "Surviving as a widow in 19th-century Montreal". In Quebec, said Bradbury (1989), « (...)The domestic labour they had been performing, crucial as it was to survival, did not prepare them for a betterpaying job which might support a family. Yet it was precisely to their skills as sewing women, housecleaners, and washerwomen that these women could and did turn when they sought employment » (p.151).

In this paper, our results shows that widows from west region do not have mature children who can support them. So this was the case in Quebec. 
Bradbury (1989) found that "Those whose husbands died while they were still relatively young, and their children were too young to work, sought jobs themselves (...). Once children were old enough to earn wages, they became the main source of support for a large number of widows ». (p.151).

Therefore, they are in great need of social support for them and their children to survive. Unfortunately, very few people and organizations see widows as a vulnerable group that needs help and which group plays a great role in the process of peace, security, and development.

But even if widows are suffering in Burundi communities, the situation is not the same with widows in Congolese communities. So in those communities, widows got many problems at the death of their husband. As mentioned by Bishop Mbemba (1971), "The "Martyrdom" of the widow begins with the last sigh of the spouse, when it has not started with the period of sickness or the hours of agony. Immediately after the death of the spouse, the family members of the spouse "tyrannize" the widow. They begin by sealing the house to prevent the widow from entering, lest she crush all the inheritance left by the deceased. Access from the house is forbidden even to children. The death vigil becomes an occasion for criticism, insults, sarcasm, slanders, accusations and vexations of all kinds of which the widow is the object. At burial, not only will he not be given the floor to address his life companion one last time, but he will be removed from the grave on the pretext that he is not from the clan of his family. After the burial of the husband, the widow continues her ordeal two to three years, during which time she is subjected to harsh prescriptions: uncut hair, sleep on the floor, ban on using soap, eating on a plate or drinking in a glass, strict defense of talking to a man,... For example, in Burundi society, this kind of treatment does not exist even if we can observe some kind of abuse".

On the day of the bereavement withdrawal, added Mbemba (1971), "if the widow refuses the new husband proposed to her, she is obliged to repay the amount of the dowry, often increased". So, this study brought more understanding on how, in other societies, widows are suffering more than others.

Helping widows is central to achieving the wider Development Goals. The UN (2001) has recognized in the past that "Programs and policies for ending violence against widows and their children, poverty alleviation, education and other support to widows of all ages also need to be undertaken, including in the context of action plan to accelerate achievement of the Millennium Development Goals." However, this has not been achieved due to the lack of specific focus on widows within the goals.

Quoting Sharpe, Hart (2009) mentioned that: "traditionally, widows were good, object of pity and sympathy, and the recipients of charity because 
the death of an earner husband almost always left them in a precarious financial position" (p.12).

Based on this study, other researchers as Okoh and Ohwoyibo (2011) have found that women form a significant proportion of our population and they constitute important resource for our socio-economic development. Women possess unique perspectives to participate in decision making and problem solving; they constitute a strong family base with increasing economic power (p. 44). This confirms our results and the ability of widows to manage well for the family well-being has also been mentioned by Blom (1990) and Hart (2009). According to them, "while widowhood created hardship for most women, they managed more successfully than widowers to overcome adversity". So, this reality is what has been understood by Sister Connection and until today, this organization is doing its best to support Burundian widows. As Pelling (1991) said in her study, we can confirm that widows are more skilled in making use of the resources available to them.

The state of widowhood can be considered as one of personal loss, encompassing everything from the immediate psychological impact of the loss of a partner to the material deprivation of an income, a home, or of unpaid contributions to the domestic economy. On the other hand, Cavallo and Warner (1999) stated that "widowhood was also a new conceptual framework or frameworks within which the widowed individual now had to function, the fact of being no longer married, with all that this implied in terms of moral reputation, relationships to one's kin, relationships to property-ownership, and even one's potential as a future marriage partner" (p. 279).

Cavallo and Warner (1999) argued that "the experience of widowhood was deeply gendered. Although widowhood was a condition which was shared by men and women alike, their contrasting experiences reflected the patriarchal society in which they lived. Explanations for such an imbalance are not difficult to find. While widowhood is a recognized dimension of women's history, widower hood has been considered until recently for its demographic rather than its social significance. Widowers were only of interest to historians because they remarried, and since they remarried faster and to a greater extent than widows, with a correspondingly shorter period of being widowed, their numerical presence in society was smaller and less prominent than widows. Above all, the loss of a wife rarely altered a man's status, while the loss of a husband invariably and irrevocably brought about a change in a woman's life." 


\section{Conclusion}

This paper contributed to a better understanding of the role played by Sister Connection in improving the living conditions of Burundian widows from west region.

Sister Connection has understood that a widow plays a great role in community development and they are supporting her by meeting her financial, social, psychological, and spiritual needs. Our results show that living conditions have been improved by the financial assistance provided by Sister Connection. Many of them got their own shelters, get their children treated when they get sick, and got the spiritual assistance. The financial assistance has improved the living conditions of widows to the extent that they are able to get food to eat, to get clothing, to send their children to school, to do gardening work, to rear livestock, get house supplies, to give offering and tithe in their churches and for some, to prepare weddings for their children.

In addition, this paper highlighted a number of constraints that Sister Connection faces in its ministry of supporting widows such us illiteracy of widows and the number of widows seeking help which is much greater than the means available to sister connection.

It is good that Sister Connection has established programs in order to meet the needs of widows. Also, such programs are playing a big role in improving their living conditions. However, participation of widows in setting priorities of their needs is of great importance for the project to be successful. Leaders of Sister Connection need to gather widows and have a talk with them about how they feel about the support they get, and together they can come to a good conclusion that is satisfying for both widows and the organization.

\section{References}

1. Bachelard, G. (1980). La formation de l'esprit scientifique. (10ème éd.). Paris : Librairie philosophique J. VRIN.

2. Beaud, S. \& Webert, F. (2003). Guide de l'enquête de terrain. Paris : La Découverte.

3. Bernier, B. (1994). Guide de présentation d'un travail de recherche, Sainte-Foy. Québec : Presses de l'Université du Québec.

4. Binczewski, J. A. (2017). Solitary sparrows: widowhood and the catholic community in post-reformation england, 1580-1630. Washington D.C.: WASHINGTON STATE UNIVERSITY, Department of History. Doctoral thesis.

5. Bradbury, B. (1989). Surviving as a widow in nineteenth century. Montreal. In Urban history Review, Vol. 17, N³, pp. 148-160. 
6. Charlier, J.-E. \& Campenhoudt, L.V. (2014). 4 méthodes de recherche en sciences sociales. Cas pratiques pour l'Afrique Francophone et le Maghreb (Sous la Direction de). Paris : DUNOD.

7. Davis, M; Kathleen and Petchesky (1977). A Descriptive Study of Some Problems of Widows in Portland, Oregon. Portland State University, Master of Social Work.

8. Hart, S. (2009). Widowhood and remarriage in colonial Australia. Thesis presented for the degree of Doctor of Philosophy. University of Western Australia.

9. Lampe, J. (2015). Empowering Widows in Africa. In The African Bulletin.

10. Loomba Foundation (2015). The Global Widows Report. A Global Overview of Deprivation Faced by Widows and their Children.

11. Lopata, H. \& Znaniecka. (1987). Widows: The Middle East, Asia, and The Pacific. Durham, Duke. University Press.

12. Mbemba, T. (1971). Pauvreté : la condition des femmes veuves dans les sociétés africaines. Brazzaville.

13. N'da, P. (2007). Méthodologie et guide pratique du mémoire de recherche et de la thèse de doctorat.

14. Okoh \& Ohwoyibo (2011). International Journal of Social and Policy Issues. Ikot Ekpene, Nigeria.

15. Pelling, M. (1991). Old Age, Poverty and disability in Early Modern Norwish: Work, Remarriage and other expedients, in Margaret Pelling and Richard M. Smith (eds), Life, death ans the Elderly. Routledge, London.

16. Sunitha Srinivas, C. (2002). Marriage and Widowhood. "Rites, rituals, and ceremonies in post-independent Indian. English fiction" Thesis. Department of English, University of Calicut.

17. Women for Human Rights, single women group (2010). International Conference on Widowhood "WIDOWS' VOICES EMPOWERED”. Baluwatar, Kathmandu, Nepal. 